\title{
Transfer of cadmium, lead, mercury and arsenic from feed into various organs and tissues of fattening lambs
}

\author{
N. G. van der Veen ${ }^{1}$ and K. Vreman ${ }^{2}$ \\ 1 State Institute for Quality Control of Agricultural Products (RIKILT), P.O. Box \\ 230, 6700 AE Wageningen, Netherlands \\ ${ }^{2}$ Institute for Livestock Feeding and Nutrition Research (IVVO), P.O. Box 160, \\ 8200 AD Lelystad, Netherlands
}

Received 26 July 1985; accepted 22 January 1986

Key words: transfer experiments, lambs, cadmium, lead, mercury, arsenic, tissues

\begin{abstract}
Transfer experiments were performed with 48 fattening lambs which were 10 weeks old. They were provided with supplementary cadmium, lead, mercury and arsenic for a period of 3 months. The elements were incorporated in wafers of concentrates as soluble compounds or such as present in harbour or sewage sludge. The administered quantity of each element as soluble compound resulted in a concentration per $\mathrm{kg}$ of dry matter in the total diet of about $2 \mathrm{mg} \mathrm{Cd}, 10 \mathrm{mg} \mathrm{Pb}, 0.1 \mathrm{mg} \mathrm{Hg}$ and $2 \mathrm{mg}$ As. For harbour sludge the concentrations were about $1,14,0.3$ and $2.5 \mathrm{mg} \mathrm{kg}^{-1}$ and for sewage sludge about $1,18,0.2$ and $1 \mathrm{mg} \mathrm{kg}^{-1}$ respectively. Of the 48 lambs 32 were kept indoors and the remainder on pasture.

Only arsenic was found at higher levels in muscle tissue due to increasing dietary concentrations. On the other hand increasing dietary concentrations of cadmium and lead resulted in higher levels of these elements in liver and kidney, especially with soluble compounds. For these compounds the concentrations of cadmium and lead were about 0.3 and $1 \mathrm{mg} \mathrm{kg}^{-1}$ respectively, both for liver and kidney. In brain tissue only lead showed increased levels, up to $0.1 \mathrm{mg} \mathrm{kg}^{-1}$.

The mercury concentrations in the kidney were about ten times higher than those in the liver. When mercury was administered as a soluble compound the concentration in the kidneys of the lambs kept on pasture was about $0.4 \mathrm{mg} \mathrm{kg}^{-1}$. Such high values are exceptional and not found in literature, even for cattle. In Dutch monitoring studies the mean concentration of mercury in kidney was lower than $0.01 \mathrm{mg}$ per $\mathrm{kg}$ fresh weight.

By dosing arsenic in the feed, some higher levels were found in the liver and kidney, however, up to $0.06 \mathrm{mg} \mathrm{kg}^{-1}$ only.
\end{abstract}




\section{Introduction}

Tolerance levels for the most toxic metals in foodstuffs, including those of animal origin such as meat, liver and kidney, are required in the Netherlands. Under Dutch circumstances sufficient data were not available for fattening lambs. Data concerning carry-over of some heavy metals in lactating dairy cows have already been reported in a previous paper (Vreman et al., 1986).

The objective of this paper is to describe carry-over experiments in which growing lambs were offered additional amounts of cadmium, lead, mercury and arsenic for about 3 months in order to examine the accumulation of these elements in muscle, liver and kidney tissues.

\section{Materials and methods}

\section{Experimental design}

The experiment was carried out over a 3-month period with 48 ram-lambs of 10 weeks old. These lambs were divided into 6 groups of 8 lambs. Two groups were kept on pasture (CP, EP); the other four groups were kept indoors (CI, EI, HI, SI). Details are summarized in Table 1.

Table 1. Summary of some experimental data, including the concentrations of elements in the whole ration (in mg per kg dry matter).

\begin{tabular}{|c|c|c|c|c|c|c|}
\hline \multirow[t]{2}{*}{ Groups } & \multicolumn{2}{|c|}{ Pasture P } & \multicolumn{4}{|c|}{ Indoors I } \\
\hline & $\mathrm{CP} *$ & $\mathrm{EP}^{*}$ & $\mathrm{CI}^{*}$ & $\mathrm{EI}^{*}$ & $\mathrm{HI}^{*}$ & $\mathrm{SI}^{*}$ \\
\hline Number of lambs & 8 & 8 & 8 & 8 & 8 & 8 \\
\hline Age in weeks at the start & 10 & 10 & 10 & 10 & 10 & 10 \\
\hline Age in weeks at the end & 24 & 24 & 24 & 24 & 24 & 24 \\
\hline Mean bodyweight, start $(\mathrm{kg})$ & 35.2 & 35.3 & 35.5 & 35.3 & 35.3 & 35.3 \\
\hline Mean body weight, end (kg) & 56.9 & 59.2 & 54.6 & 55.6 & 57.3 & 54.9 \\
\hline Mean daily dry matter intake of concentrates $(\mathrm{g})$ & 258 & 258 & 1067 & 1062 & 1165 & 1150 \\
\hline Estimated daily dry matter intake of grass $(\mathrm{g})$ & 1100 & 1100 & - & - & - & - \\
\hline Mean daily dry matter intake of hay $(\mathrm{g})$ & - & - & 231 & 213 & 223 & 227 \\
\hline Cd in whole ration & $<0.1$ & 1.6 & $<0.1$ & 2.8 & $\begin{array}{c}1.1 \\
(0.5)\end{array}$ & $\begin{array}{c}0.8 \\
(0.3)\end{array}$ \\
\hline $\mathrm{Pb}$ in whole ration & 2.5 & 10 & 1.4 & 12.9 & $\begin{array}{l}13.8 \\
(9.4)\end{array}$ & $\begin{array}{l}17.9 \\
(9.0)\end{array}$ \\
\hline $\mathrm{Hg}$ in whole ration & $<0.02$ & 0.08 & $<0.02$ & 0.14 & $\begin{array}{c}0.27 \\
(0.18)\end{array}$ & $\begin{array}{c}0.17 \\
(0.07)\end{array}$ \\
\hline As in whole ration & 0.3 & 1.6 & 0.3 & 2.6 & $\begin{array}{c}2.5 \\
(1.1)\end{array}$ & $\begin{array}{c}0.9 \\
(0.4)\end{array}$ \\
\hline
\end{tabular}

* C refers to the control group.

E refers to the experimental group offered soluble compounds.

$\mathrm{H}$ refers to the group offered harbour sludge.

$S$ refers to the group offered sewage sludge.

$P$ and $I$ refer to pasture and indoors respectively.

Concentrations in the second half of the experimental period when $5 \%$ sludge was included in the concentrates are given in parenthesis. 
Table 2. Mean concentrations of cadmium, lead, mercury and arsenic in the different feeds (in $\mathrm{mg} \mathrm{kg}^{-1}$ dry matter).

\begin{tabular}{lllllll}
\hline Feed & $\begin{array}{l}\text { \% dry } \\
\text { matter }\end{array}$ & \multicolumn{1}{l}{ Cd } & Pb & Hg & As & $\begin{array}{l}\text { Destined for } \\
\text { groups }\end{array}$ \\
& 18.3 & $<0.1$ & 2.8 & 0.02 & 0.32 & CP, EP \\
Grass & 83.3 & $<0.1$ & 2.8 & 0.02 & 0.25 & CI, EI, HI, SI \\
Hay & 86.8 & $<0.1$ & 1.0 & $<0.01$ & 0.15 & CP, CI \\
Concentrate A & 86.8 & 7.8 & 42 & 0.34 & 7.2 & EP \\
Concentrate B $^{*}$ & 86.8 & 3.4 & 15 & 0.16 & 3.1 & EI \\
Concentrate C & 87.5 & 1.3 & 16 & 0.32 & 2.9 & HI \\
Concentrate D & 86.6 & 1.0 & 21 & 0.20 & 1.0 & SI \\
Concentrate E & 81.0 &
\end{tabular}

* Concentrations were not similar because concentrate intake for lambs on pasture was much lower than that for lambs kept indoors.

The administered soluble compounds were cadmium, lead and mercury acetate and arsenic trioxide. These compounds were added to concentrates via premixes and given to the experimental groups EP and EI. The administered quantity of each metal resulted in a total concentration in the total diet as shown in Table 1. The control groups $\mathrm{CP}$ and $\mathrm{CI}$ received concentrates without additional metal compounds.

The group HI, kept indoors, received harbour sludge mixed in the concentrates, whereas the group SI received sewage sludge. During the first half of the experiment (about 6 weeks) the concentrates contained $10 \%$ of sludge. Due to suboptimal intake of concentrates the percentage of sludge was reduced to 5 in the second 6-week period.

Table 2 gives the mean values of cadmium, lead, mercury and arsenic in the different feeds.

The transfer experiments were performed at the experimental farm of the Institute for Livestock Feeding and Nutrition Research (IVVO) in Lelystad.

\section{Sampling}

During each month of the trial period composite grass samples were taken from grazed pasture. Concentrates and hay were also sampled periodically.

At the end of the trial (after 3 months of treatment) the animals were slaughtered and carefully sampled to obtain tissues for analysis. Feed samples were dried to a dry matter content of about $95 \%$ and stored at $2-4{ }^{\circ} \mathrm{C}$. Animal product samples were stored at about $-20{ }^{\circ} \mathrm{C}$ until required for analysis. Samples for analysis were carefully obtained by removing gross blood, connective tissue and fat from organs and by comminuting and freeze-drying these tissues.

The analyses were carried out at the State Institute for Quality Control of Agricultural Products (RIKILT) in Wageningen.

\section{Analytical procedures}

Cadmium and lead in feeds, liver and kidney were determined by dry-ashing of the samples, followed by a flame atomic absorption spectrometric measurement after 
complexing of the elements with a complexing agent.

Cadmium and lead in meat and brain were measured by differential pulse anodic stripping voltametry after dry-ashing of the samples. Mercury was determined by cold vapour atomic absorption spectrometry after acid decomposition of the samples in a destruction bomb. Arsenic was determined by hydride atomic absorption spectrometry after dry-ashing of the samples.

Details are described in a previous paper (Vreman et al., 1986).

\section{Results}

Table 1 summarizes some experimental data, together with concentrations of cadmium, lead, mercury and arsenic in the whole ration. These concentrations can be calculated with the data listed in Table 2 for the concentrations of the elements in the different feeds and the amounts for the components of the diet listed in Table 1. The amounts of these elements in water hardly contribute to the intake via feeds. The average intakes of cadmium, lead, mercury and arsenic from water were 20, 1 , 0.4 and $40 \mu \mathrm{g}$ respectively, assuming an average daily intake of 4 litres of water per lamb.

Table 3 gives the concentrations of the elements found in muscle tissue. Within each group 6 samples were analysed. These 6 samples were from 2 lambs. From each lamb the muscle samples were taken from 3 sites on the carcass, i.e. the upper arm, the diaphragm and the tail head. Muscle tissue from the remaining 4 lambs was not analysed because previous transfer experiments with cows (Vreman et al., 1986) did not show relevant accumulation of the elements mentioned above. Although not shown in this table, there were no significant differences between the concentrations of the elements at the three mentioned different sites of the carcass.

Tables 4 and 5 give the results for liver and kidney respectively.

Within each group 5 samples were analysed for cadmium and lead and 4 samples for mercury and arsenic. For the brain (Table 6) 1 sample from each of the control

Table 3. Concentrations of elements (mean and standard deviation of mean in $\mu \mathrm{g}$ per $\mathrm{kg}$ fresh weight) in 6 samples of muscle tissue and \% dry matter.

\begin{tabular}{|c|c|c|c|c|c|c|}
\hline Group & Description & $\mathrm{Cd}$ & $\mathrm{Pb}$ & $\mathrm{Hg}$ & As & $\%$ dry matter \\
\hline $\mathrm{CP}$ & $\begin{array}{l}\text { Control } \\
\text { Pasture }\end{array}$ & $3 \pm 1$ & $23 \pm 3$ & $1 \pm 1$ & $2 \pm 1$ & $32.3 \pm 1.5$ \\
\hline EP & $\begin{array}{l}\text { Soluble comp. } \\
\text { Pasture }\end{array}$ & $3 \pm 1$ & $17 \pm 3$ & $3 \pm 2$ & $2 \pm 1$ & $32.8 \pm 2.0$ \\
\hline $\mathrm{CI}$ & $\begin{array}{l}\text { Control } \\
\text { Indoors }\end{array}$ & $2 \pm 1$ & $23 \pm 8$ & $2 \pm 1$ & $3 \pm 1$ & $30.5 \pm 1.6$ \\
\hline EI & $\begin{array}{l}\text { Soluble comp. } \\
\text { Indoors }\end{array}$ & $1 \pm 1$ & $17 \pm 3$ & $1 \pm 1$ & $14 \pm 3$ & $29.5 \pm 1.5$ \\
\hline HI & $\begin{array}{l}\text { Harbour sludge } \\
\text { Indoors }\end{array}$ & $2 \pm 1$ & $13 \pm 2$ & $1 \pm 1$ & $12 \pm 1$ & $30.5 \pm 1.3$ \\
\hline SI & $\begin{array}{l}\text { Sewage sludge } \\
\text { Indoors }\end{array}$ & $4 \pm 1$ & $22 \pm 3$ & $1 \pm 1$ & $3 \pm 1$ & $29.1 \pm 1.4$ \\
\hline
\end{tabular}


Table 4. Concentrations of elements (mean and standard deviation of mean in $\mu \mathrm{g} \mathrm{per} \mathrm{kg}^{-1}$ fresh weight) in liver and \% dry matter. ${ }^{1}$

\begin{tabular}{|c|c|c|c|c|c|c|}
\hline Group & Description & $\mathrm{Cd}$ & $\mathrm{Pb}$ & $\mathrm{Hg}$ & As & $\%$ dry matter \\
\hline $\mathrm{CP}$ & $\begin{array}{l}\text { Control } \\
\text { Pasture }\end{array}$ & $22 \pm 2(5)$ & $1222 \pm 125(5)$ & $14 \pm 2(4)$ & $2 \pm 1(4)$ & $33.8 \pm 0.8(5)$ \\
\hline $\mathrm{EP}$ & $\begin{array}{l}\text { Soluble comp. } \\
\text { Pasture }\end{array}$ & $198 \pm 63(5)$ & $1634 \pm 95(5)$ & $13 \pm 1(4)$ & $4 \pm 1(4)$ & $33.5 \pm 0.9(5)$ \\
\hline CI & $\begin{array}{l}\text { Control } \\
\text { Indoors }\end{array}$ & $20 \pm 5(5)$ & $544 \pm 38(5)$ & $16 \pm 3(4)$ & $4 \pm 1(4)$ & $31.3 \pm 0.9(5)$ \\
\hline EI & $\begin{array}{l}\text { Soluble comp. } \\
\text { Indoors }\end{array}$ & $252 \pm 53(5)$ & $1092 \pm 51(5)$ & $28 \pm 8(4)$ & $24 \pm 3(4)$ & $32.1 \pm 0.5(5)$ \\
\hline HI & $\begin{array}{l}\text { Harbour sludge } \\
\text { Indoors }\end{array}$ & $56 \pm 8(5)$ & $582 \pm 48(5)$ & $37 \pm 8(4)$ & $24 \pm 7(4)$ & $31.3 \pm 1.0(5)$ \\
\hline SI & $\begin{array}{l}\text { Sewage sludge } \\
\text { Indoors }\end{array}$ & $58 \pm 5(5)$ & $642 \pm 119(5)$ & $34 \pm 8$ & $8 \pm 3(4)$ & $31.3 \pm 0.5(5)$ \\
\hline
\end{tabular}

${ }^{1}$ Number of samples in parenthesis.

Table 5. Concentrations of elements (mean and standard deviation of mean in $\mu \mathrm{g}$ per $\mathrm{kg}$ fresh weight) in kidney and \% dry matter. ${ }^{1}$.

\begin{tabular}{|c|c|c|c|c|c|c|}
\hline Group & Description & $\mathrm{Cd}$ & $\mathrm{Pb}$ & $\mathrm{Hg}$ & As & $\%$ dry matter \\
\hline $\mathrm{CP}$ & $\begin{array}{l}\text { Control } \\
\text { Pasture }\end{array}$ & $34 \pm 2(5)$ & $498 \pm 76(5)$ & $178 \pm 15(4)$ & $5 \pm 1(4)$ & $21.5 \pm 0.6(5)$ \\
\hline EP & $\begin{array}{l}\text { Soluble comp. } \\
\text { Pasture }\end{array}$ & $230 \pm 36(5)$ & $760 \pm 61(5)$ & $143 \pm 13(4)$ & $10 \pm 2(4)$ & $21.4 \pm 0.2(5)$ \\
\hline $\mathrm{CI}$ & $\begin{array}{l}\text { Control } \\
\text { Indoors }\end{array}$ & $28 \pm 4(5)$ & $260 \pm 68(5)$ & $238 \pm 37(4)$ & $7 \pm 1(4)$ & $20.8 \pm 0.3(5)$ \\
\hline EI & $\begin{array}{l}\text { Soluble comp. } \\
\text { Indoors }\end{array}$ & $300 \pm 58(5)$ & $1132 \pm 160(5)$ & $360 \pm 56(4)$ & $41 \pm 4(4)$ & $19.7 \pm 0.4(5)$ \\
\hline HI & $\begin{array}{l}\text { Harbour sludge } \\
\text { Indoors }\end{array}$ & $70 \pm 10(5)$ & $446 \pm 93(5)$ & $265 \pm 30(4)$ & $57 \pm 4(4)$ & $20.4 \pm 0.5(5)$ \\
\hline SI & $\begin{array}{l}\text { Sewage sludge } \\
\text { Indoors }\end{array}$ & $56 \pm 4(5)$ & $310 \pm 93(5)$ & $254 \pm 19(4)$ & $18 \pm 3(4)$ & $19.0 \pm 0.6(5)$ \\
\hline
\end{tabular}

${ }^{1}$ Number of samples in parenthesis.

Table 6. Concentrations of elements (in $\mu \mathrm{g}$ per $\mathrm{kg}$ fresh weight) in the brain and $\%$ dry matter (from every group one sample is analysed).

\begin{tabular}{|c|c|c|c|c|c|c|}
\hline Group & Description & $\mathrm{Cd}$ & $\mathrm{Pb}$ & $\mathrm{Hg}$ & As & $\%$ dry matter \\
\hline $\mathrm{CP}$ & $\begin{array}{l}\text { Control } \\
\text { Pasture }\end{array}$ & 6 & 40 & 1 & 1 & 24.3 \\
\hline EP & $\begin{array}{l}\text { Soluble comp. } \\
\text { Pasture }\end{array}$ & 5 & 100 & 1 & 1 & 23.8 \\
\hline CI & $\begin{array}{l}\text { Control } \\
\text { Indoors }\end{array}$ & 1 & 40 & 1 & 1 & 23.6 \\
\hline EI & $\begin{array}{l}\text { Soluble comp. } \\
\text { Indoors }\end{array}$ & 3 & 90 & 1 & 2 & 24.6 \\
\hline
\end{tabular}


groups ( $\mathrm{CP}$ and $\mathrm{CI})$ and one from each of the groups dosed with soluble compounds (EP and EI) were analysed.

\section{Discussion}

\section{Muscle tissue and brain}

The concentrations of cadmium, lead and mercury in muscle tissue are equal same for each group, which means that no accumulation occurs in this tissue via the feed (Table 3). Arsenic gives some accumulation for the groups kept indoors and fed on concentrates containing soluble compounds and harbour sludge (groups EI and $\mathrm{HI}$ ). Nevertheless, the concentrations of arsenic are low and below the Dutch proposed action level of $30 \mu \mathrm{g} \mathrm{kg}^{-1}$ for beef. This action level, together with those for cadmium, lead and mercury of 50,200 and $25 \mu \mathrm{g} \mathrm{kg}^{-1}$ respectively, was derived from monitoring and transfer studies. If during monitoring such a level is reached or exceeded, tracing the sources of contamination in dairy cattle will be considered necessary.

For cadmium, lead and mercury also proposed tolerance values have been established. These are for beef 50,400 and $50 \mu \mathrm{g} \mathrm{kg}^{-1}$ respectively (Klitsie, 1983).

The obtained results for muscle tissue are below $10 \%$ of these values and correspond with Dutch monitoring studies (van der Veen, 1983). Results from German monitoring research are on average slightly higher (Knöppler et al., 1979). Doyle et al. (1974) reported in transfer experiments results for cadmium in muscle tissue of $25 \mu \mathrm{g} \mathrm{kg}^{-1}$ (fresh weight) for the control group and twice as much for the group offered $5 \mathrm{mg} \mathrm{kg}{ }^{-1} \mathrm{Cd}$ in the total diet. Dalgarno (1980) reported concentrations of cadmium in muscle tissue lower than $12 \mu \mathrm{g} \mathrm{kg}^{-1}$ and no significant increases in the lambs receiving Cd-supplemented diets. Kögel (1981) found concentrations of cadmium in muscle tissue of $6 \mu \mathrm{g} \mathrm{kg}^{-1}$ for the control group and no significant accumulation with increasing dietary $\mathrm{Cd}$ content. These results correspond with the present study. Koivistoinen (1980) reported in a Finnish monitoring study with sheep concentrations of cadmium, lead, mercury and arsenic of $<5,20,<2$ and $<20 \mu \mathrm{g}$ per kg fresh weight. These values also correspond with the present study.

In brain tissue the concentrations found for cadmium and mercury are comparable with those for muscle tissue, whereas the lead concentrations are somewhat higher in brain. Compared with the control groups the groups dosed with soluble compounds give some higher concentrations. For all groups the concentration of arsenic in brain tissue is very low.

\section{Liver and kidney}

Mean values of lead in livers from the lambs kept on pasture are higher than those from the lambs kept indoors (Table 4). Although the lead concentration of about $1200 \mu \mathrm{g} \mathrm{kg}^{-1}$ for the group $\mathrm{CP}$ is high in comparison with German monitoring research (Knöppler, 1979), where values ranged mostly from 300 to $500 \mu \mathrm{g} \mathrm{kg}^{-1}$, the high value mentioned corresponds with Dutch monitoring studies with sheep, where values ranged from 10 to 3500 with a mean value of about $1000 \mu \mathrm{g} \mathrm{kg}^{-1}$ (van der Veen, 1983). 
For kidney (Table 5) the mean values of lead for each group are lower than those for liver. This is also reported in the Dutch and German monitoring research mentioned above. For lead the Dutch monitoring study gives a mean value of about 450 $\mu \mathrm{g} \mathrm{kg}^{-1}$. From the results obtained for lead in both liver and kidney it can be concluded that accumulation via the feed occurs in particular when the animals are dosed the element as soluble compound. Although the lead concentration in the whole ration with harbour or sewage sludge is higher than that containing soluble compounds, this is not found in liver and kidney. Maybe (as stated by Rosenberger et al., 1976) the type of bonding between the element and the sludge particles or the particle size itself affects the uptake of lead.

The mean concentrations of lead in livers of sheep from the experimental groups and the control group kept on pasture exceed the maximum permitted concentration for cattle liver, being $1.0 \mathrm{mg}$ per $\mathrm{kg}$ fresh weight (Klitsie, 1983). Koivistoinen (1980) reported mean concentrations of lead in liver and kidney of 30 and $110 \mu \mathrm{g}$ $\mathrm{kg}^{-1}$ respectively. These concentrations are extremely low in comparison with the present results obtained for the control groups.

The concentrations of cadmium in liver and kidney (Tables 4 and 5) of both control groups are lower than values found for sheep in monitoring studies (van der Veen, 1983), where mean values of 50 and $150 \mu \mathrm{g} \mathrm{kg}^{-1}$ are reported respectively. The concentrations in both organs are almost equal. In the kidneys from cows and pigs the previously mentioned monitoring studies showed mean values for cadmium of about $300 \mu \mathrm{g} \mathrm{kg}^{-1}$, i.e. ten times higher than for sheep. In other transfer experiments higher results are found in kidney than in liver. Mills et al. (1972) reported concentrations of 500 and $1200 \mu \mathrm{g} \mathrm{kg}^{-1}$ (fresh weight) in liver and kidney respectively when lambs are dosed with cadmium at $3.5 \mathrm{mg} \mathrm{kg}^{-1}$ in the diet for about 8 weeks. Transfer experiments performed by Doyle et al. (1974) resulted in mean concentrations in the liver and kidney tissue from lambs of about 550 and $880 \mu \mathrm{g}$ $\mathrm{kg}^{-1}$ (fresh weight) respectively for the control group and about 5000 and $12000 \mu \mathrm{g}$ $\mathrm{kg}^{-1}$ for the group offered $5 \mathrm{mg} \mathrm{kg}^{-1}$ of cadmium in their diet over a period of 191 days. Again, the results in kidney tissue are higher than those in liver. On the other hand the concentrations of cadmium in the liver and kidney tissue of the control group are extremely high compared with those observed in recent Dutch transfer experiments.

Hapke et al. (1977) found concentrations of $200 \mu \mathrm{g} \mathrm{kg}^{-1}$ for both liver and kidney tissue in lambs fed on uncontaminated feed for 140 days. Dalgarno (1980) reported significant increases in tissue cadmium in both liver and kidney with increasing dietary cadmium, with a concentration in the kidney being approximately five times higher than that in the liver. At a dietary cadmium concentration of $3.4 \mathrm{mg}$ per kg dry matter the mean concentrations for liver and kidney are 1300 and $3600 \mu \mathrm{g} \mathrm{kg}^{-1}$ respectively. At a dietary concentration of $0.31 \mathrm{mg} \mathrm{kg}^{-1}$ these concentrations are 40 and $350 \mu \mathrm{g} \mathrm{kg}^{-1}$. Kögel et al. (1981) reported concentrations in liver and kidney for the control group of 55 and $84 \mu \mathrm{g} \mathrm{kg}^{-1}$ respectively, and after giving dietary cadmium at about $2 \mathrm{mg} \mathrm{kg}^{-1}$ for 115 days concentrations of 1380 and $1500 \mu \mathrm{g} \mathrm{kg}^{-1}$ are found. The results of the control group are slightly higher than those in this present study. Koivistoinen (1980) reported mean concentrations for liver and kidney of 60 
and $140 \mu \mathrm{g} \mathrm{kg}^{-1}$ respectively. These results are also higher than those found in the present trial, but correspond with results found in Dutch monitoring research (van der Veen, 1983).

There is a significant increase in cadmium concentration in liver and kidney with increasing dietary cadmium, but the results are much less pronounced than found in literature. Compared with Dutch tolerance levels for cow liver and kidney of 1000 and $3000 \mu \mathrm{g} \mathrm{kg}^{-1}$ respectively (Klitsie, 1983), the results for the experimental groups are low. Just as for lead the type of bonding between the element and the sludge particles or the particle size itself could influence the uptake of cadmium, as can be seen from the Tables 1,4 and 5 .

The concentrations of mercury in liver (Table 4) of the control groups are comparable with values found in German monitoring studies (Knöppler et al., 1979). In Dutch monitoring research (van der Veen, 1983) the results for sheep liver are about $3 \mu \mathrm{g} \mathrm{kg}^{-1}$ and for sheep kidney $5 \mu \mathrm{g} \mathrm{kg}^{-1}$. In this study the concentrations of mercury found in kidney tissue (Table 5) are extremely high, even for the control groups. Such high concentrations were not found in other studies. For example, Koivistoinen (1980) found a mean mercury concentration for kidney of $7 \mu \mathrm{g} \mathrm{kg}^{-1}$ and for liver of $3 \mu \mathrm{g} \mathrm{kg}^{-1}$. The concentrations found in kidneys (Table 5) all exceed the proposed tolerance value of $100 \mu \mathrm{g} \mathrm{kg}^{-1}$ for cow kidney (Klitsie, 1983).

For arsenic the concentrations in liver (Table 4) and kidney (Table 5) are low, especially for the groups kept on pasture. Koivistoinen (1980) reported a value below $20 \mu \mathrm{g} \mathrm{kg}^{-1}$ for sheep liver. For the groups kept indoors there is a significant increase in arsenic concentration in relation to the dietary increase. However the concentrations are low.

\section{Acknowledgements}

The authors thank all who cooperated in this study. In particular they are grateful to Mrs A. H. J. Berghmans-van Megen, Mrs A. M. G. Betteray-Kortekaas, Mrs A. W. Hoff, Mrs J. P. C. Hovens, Mr H. J. Horstman and Mr J. J. M. H. Teeuwen for their analytical work.

\section{References}

Dalgarno, A. C., 1980. The effect of low level exposure to dietary cadmium, on cadmium, zinc, copper and iron contents of selected tissues of growing lambs. Journal of the Science of Food and Agriculture 31: $1043-1049$.

Doyle, J. J., W. H. Pfander, S. E. Grebing \& J. O. Pierce, 1974. Effect of dietary cadmium on growth, cadmium absorption and cadmium tissue levels in growing lambs. Journal of Nutrition 104: 160-166.

Hapke, H. J., J. Abel, U. Kühl \& U. Glaser, 1977. Die Ansammlung von Cadmium in verzehrbahren Geweben in Abhängigkeit von der Cadmium-Menge im Futter. Archiv für Levensmittelhygiene 59: 174-177.

Klitsie, C. G. M., 1983. Ontwerpnormen voor cadmium, lood en kwik. Bedrijfsontwikkeling 14: $502-$ 504.

Knöppler, H. O., W. Graunke, W. Müncke, H. Schulze \& W. Gedek, 1979. Blei-, Cadmium- und Quecksilbergehalte in Fleisch- und Organproben von Lämmern und Schafen. Fleischwirtschaft 5: 241247. 
Kögel, J., P. Hofmann, A. Rosopulo \& H. O. Knöppler, 1981. Untersuchungen zum Übergang von Cadmium aus natürlich kontaminierten Futtermitteln auf die Tiere. Landwirtschaftliche Forschung 37: 369-372.

Koivistoinen, P., 1980. Mineral element composition of Finnish foods. Acta Agriculturae Scandinavica Suppl. 22: 57-76.

Mills, C. F. \& A. C. Dalgarno, 1972. Copper and zinc status of ewes and lambs receiving increased dietary concentrations of cadmium. Nature 239: 171-173.

Rosenberger, G., H. D. Gründler \& G. Crössmann, 1976. Untersuchungen über Aufnahme und Anreicherung von Schwermetallen bei Milchkühen durch Verfütterung von zink, blei- und cadmiumhaltigem Industriestaub. Deutsche Tierärtzliche Wochenschrift 83: 471-514.

Veen, N. G. van der, 1983. Cadmium in dierlijke produkten. Bedriffsontwikkeling 14: 497-499.

Veen, N. G. van der, 1983. Gehalten aan lood, cadmium, kwik en arseen in monsters vlees en organen van runderen, varkens, schapen en pluimvee, bemonsterd over 1982 en vergeleken met resultaten over 1981. RIKILT-Verslag 83.30, Wageningen, 22 pp.

Vreman, K., N. G. van der Veen, E. J. van der Molen \& W. G. de Ruig, 1986. Transfer of cadmium, lead, mercury and arsenic from feed into milk and various tissues of dairy cows: chemical and pathological data. Netherlands Journal of Agricultural Science 34: 000-000. 